\title{
Role of the Media in Health-Related Awareness Campaigns on Perceptions of COVID-19: A Pre-Post Study in the General Population of Pakistan
}

\section{Atta Ur Rehman}

University of the Punjab

\section{Rubeena Zakar}

University of the Punjab

Muhammaz Zakria Zakar

University of Okara

Ume Hani

Rawalpindi Medical University

Florian Fischer ( $\nabla$ florian.fischer1@charite.de)

Charite Universitatsmedizin Berlin https://orcid.org/0000-0002-4388-1245

Research article

Keywords: health communication, health education, community education, electronic media, SARS-CoV-2

Posted Date: October 27th, 2020

DOl: https://doi.org/10.21203/rs.3.rs-76623/v1

License: (c) (i) This work is licensed under a Creative Commons Attribution 4.0 International License. Read Full License

Version of Record: A version of this preprint was published at Frontiers in Public Health on November 12th, 2021. See the published version at https://doi.org/10.3389/fpubh.2021.779090. 


\section{Abstract}

Background: In January 2020, the World Health Organization declared the COVID-19 outbreak a global public health emergency. Medical preparedness and community education are the most valuable preventive tools for combatting this pandemic. The objective of this study was to assess the role of media public health awareness campaigns on the knowledge of the general population about COVID-19 in Rawalpindi, Pakistan.

Methods: A quantitative study using a pre-post design among 384 respondents was conducted. To recruit study participants, a systematic random sampling technique was used. A structured questionnaire was administered to the participants twice: The first response $\left(t_{1}\right)$ from participants was filled in during the first week in February 2020 before any confirmed cases were reported in the country, and the second response $\left(t_{2}\right)$ was completed one month after the first case detection in Pakistan (March 2020). Media health awareness campaigns were launched just after the detection of the first case in Pakistan. Data was analysed by computing descriptive statistics and paired t-tests to measure the level of association between variables.

Results: Exposure to the media and knowledge relating to COVID-19, particularly its symptoms and frequent handwashing as a preventive measure, increased over time. Whereas only a quarter of respondents judged the isolation of suspected cases in quarantine to be important to prevent the spread of infection in society at $t_{1}$, more than half did so at $t_{2}$. The same increase was visible in relation to the statement that a lockdown helps to follow social distancing. Socio-demographic characteristics were not significantly associated with knowledge (gains). However, more frequent use of electronic media is associated with greater knowledge gains from $t_{1}$ to $t_{2}$.

Conclusions: The findings of this study provide evidence that awareness and knowledge related to COVID-19 symptoms and preventive measures increased significantly over time. The increased frequency of following the media indicates that health awareness campaigns are important for enhancing the knowledge of the general public regarding COVID-19.

\section{Background}

On 30 January 2020, the World Health Organization (WHO) declared the Novel Coronavirus Disease 2019 (COVID-19) outbreak to be a global public health emergency (1). Coronaviruses are a microbial source of infections in individuals, with a spectrum of activity associated with the common cold, Severe Acute Respiratory Syndrome (SARS), and Middle East Respiratory Syndrome (MERS) (2). The morbidity of endemic coronavirus respiratory infections in the last decade was $15-30 \%$. The elderly, neonates, diabetics, and immunocompromised people are the most vulnerable groups when infected by coronaviruses (3). The outbreak of a pneumonia of unknown cause was observed in Wuhan, China, in December 2019. A novel coronavirus (SARS-CoV-2) was isolated from patients in Wuhan in January 2020 (4). This outbreak - and the associated strict isolation - attracted global attention. The movement of 
people along the road passage from Iran and air travel from other countries brought the virus to Pakistan, which confirmed its first case on 26 February 2020 (5). The number of active COVID-19 cases in Pakistan was 6,726 on 9 September 2020 , with 6,350 confirmed deaths (6).

Medical preparedness and community education are the most valuable preventive tools for combatting the pandemic $(7,8)$. The media has already been serving as an important source of health education and promotion in our societies for decades (9). Health-related communication campaigns in the media have aimed to change the health behaviour of the population by creating awareness and promoting prevention, such as hand hygiene practices and immunization coverage (9-11). Health campaigns are categorized into typical and digital technology use campaigns. Typical communication involves the use of different media channels (e.g. print media or electronic media), whereas digital technology communication may involve the use of mobile phones and internet web search engines (9). Health communication plays a vital role in behavioural changes (12) and may, finally, result in modifications in the awareness, attitudes, and practices of the targeted audience for improving health.

The government of Pakistan, in collaboration with the WHO, established isolation units in leading hospitals, set up screening facilities at border entry points, seaports and airports, facilitated quarantine areas at selected places, provided personal protective equipment for healthcare professionals, and enforced lockdown in cities to break the chain of infection (13). In Pakistan, the media started to report about the epidemic when it first appeared in Wuhan, but its reporting increased drastically, with more focus on preventive measures, after the first reported case in Pakistan on 26 February 2020 (5). COVID-19 has been linked with population anxiety globally (14). Mental stress, as well as health literacy, may have increased due to public reporting. The awareness campaign in the different communication media in Pakistan emphasized the symptoms of the disease, preventive measures, and the importance of social distancing. Symptoms of a coronavirus disease may appear within two to fourteen days after viral exposure. The symptoms may include a fever, cough, headache, sore throat, shortness of breath, and rapid heartbeat, with complications of pneumonia and organ failure. Treatment options are only supportive because no targeted anti-viral therapeutics are available at present (15). There is currently no vaccination against COVID-19 available (16). Protective measures adopted by the general population should include frequent handwashing, use of hand sanitizers, avoiding close contact with sick people, and social distancing practices (17). This study investigated the role of the media as an awareness creator. The objectives of the study were to evaluate the role of media health-awareness campaigns on the general population's perception and knowledge of COVID-19 in Rawalpindi, Pakistan.

\section{Methods}

\section{Study design}

A quantitative research method based on a pre-post study design was used to collect data from the general population in Rawalpindi, which is the fourth most populous city in Pakistan (18). Data was collected in a community pharmacy, because healthcare facilities, including pharmacies, were allowed to 
practise when the lockdown was implemented in all countries. They are places that are frequently visited by the general public for prescription refilling for relatives, health accessories, and cosmeceutical purchases. Pharmacies also maintain records of visitors, with contact information that enabled us to get the final response. The respondents were regular clients of the community pharmacy in Rawalpindi, who visited every month. The adult population using the media as a source of health awareness, not currently labelled as patients by any prescriber, and being willing to participate were included in the study. The data was collected from Rawalpindi because it was among the top three cities in terms of number of COVID-19 cases in Punjab (19). The second reason was that the visitors' record at the pharmacy was well maintained, which was essential for the post phase of the study.

\section{Sample size and sampling technique}

The sample size was calculated on the hypothesis that knowledge prevalence $(P)$ would be $50 \%$, with an allowable error ( $d$ ) of $5 \%$ and a confidence level of $95 \%(z=1.96)$. The following formula (20) was used:

$$
n=\frac{z^{2} \cdot P \cdot(1-P)}{d^{2}}=\frac{1.96^{2} \cdot 0.5 \cdot(1-0.5)}{0.05^{2}}=384
$$

Therefore, 384 respondents were selected. The technique used for the data collection was systematic random sampling, because the public was rationally similar. Each wave of the study needed to be completed within one week. As the average population visiting the pharmacy every week was $n=1,920$, the sampling interval was $k=5$. The first respondent was chosen in February by using a software method for simple random sampling. The first respondent selected was visitor number 3 . Then, by the addition of participants at the regular interval $(k=5)$, the sample size was completed. The same participants completed the second response. The response rate was $100 \%$, as all 384 questionnaires were received back and filled out completely.

\section{Items of interest}

The survey was based on a self-designed structured questionnaire (Supplementary Appendix 1). The tool consisted of three sections. The first section comprised information on the socio-demographics of the participants, including age, gender, marital status, place of residence, level of education, and income. The second section was related to the history of the frequency of using different types of media. Questions were related to social media, electronic media, and print media. The third segment concerned knowledge regarding COVID-19 symptoms, complications, and preventive measures to be adopted regarding COVID19 , and the effect of lockdowns on social isolation. The respondents were asked to answer whether several statements were correct ("Yes", "No", or "Don't know").

Correct statements were valued with one point each and summed (without weighting) in three subscales related to knowledge (general, symptoms, and preventive measures) and an overall total scale (ranging from $0=$ "No knowledge" to $19=$ "Full knowledge"). The subscales included a five-item subscale related to general awareness (i.e. coronavirus is contagious, spread through droplets, spread through coughing 
and sneezing by an infected person, coronavirus treatment is only supportive, and no vaccine is available), a six-item subscale on symptoms and complications (i.e. fever, cough, body aches, shortness of breath, pneumonia, organ failure), and an eight-item subscale on preventive measures (frequent handwashing with soap and water, following cough and sneeze etiquette, avoiding social contact with sick people, use of face masks, use of hand sanitizers, isolation of suspected cases, lockdowns to follow social distancing, and lockdowns resulting in more self-protection). The questionnaire's construct validity and reliability were evaluated by factor analysis and Cronbach's alpha respectively. The Kaiser-MeyerOkin measure was 0.89 with significant Bartlett's test. Three components were extracted to measure the underline construct. The reliability Cronbach alpha value was 0.899 for the subscale of general awareness, 0.922 for the subscale of symptoms and complications, and 0.873 for the preventive measure subscale.

\section{Media awareness intervention}

This study investigates the role of the media in shaping the perceptions of the general population visiting a community pharmacy in Rawalpindi, Pakistan, towards COVID-19. The sampled population comprised of individuals utilizing any type of media for public health awareness. The first response from participants was filled out during the first week of February 2020 before any confirmed cases were reported in Pakistan $\left(t_{1}\right)$. Media awareness and prevention campaigns for COVID-19 started just after the detection of the first case on 26 February 2020, and reached a peak in March 2020 in Pakistan. Lockdown in the country also created curiosity related to COVID-19 in the general public (21-23). The national disaster management authority, Pakistan's telecommunications authority, as well as electronic and print media were continuously providing awareness alerts and preventive communications. The health education and prevention interventions by the media comprised of comprehensive education on coronavirus awareness, along with the screening and preventive measures that needed to be adopted to stay healthy and safe from COVID-19. During the last week of March, the second response was collected from each participant $\left(\mathrm{t}_{2}\right)$, giving an eight-week interval between the two surveys.

\section{Data analysis}

The data was analysed using SPSS version 21 (24). We applied descriptive and inferential statistical methods. Frequencies and percentages were computed for summary statistics. We used correlation tests for the association between the different media types. The research aims to describe the potential change in population perceptions regarding COVID-19, following media campaign exposure during February and March 2020. Statistical tests such as the paired t-test and chi-square test were used to assess changes in the population's perceptions during subsequent months.

The factors associated with knowledge were assessed using three linear regression models. The dependent variables were the overall scores for knowledge related to COVID-19 at $t_{1}$ and $t_{2}$, and for the knowledge gains over time (between $t_{1}$ and $t_{2}$ ). Independent variables were the variables related to media use and socio-demographic characteristics, such as those described in Table 1, except for education, 
which was categorized as a binary variable ("12 years or fewer" vs. "13 years or more") to allow for large enough sub-groups in the regression models. The $\mathrm{R}^{2}$ was calculated as the coefficient of determination. 
Table 1

Sociodemographic characteristics of respondents $(\mathrm{n}=384)$

\begin{tabular}{|c|c|}
\hline Sociodemographic characteristics & $n(\%)$ \\
\hline \multicolumn{2}{|l|}{ Age (in years) } \\
\hline $16-30$ & $59(15.4)$ \\
\hline $31-45$ & $62(16.1)$ \\
\hline $46-60$ & $178(46.4)$ \\
\hline $61-75$ & $85(22.1)$ \\
\hline \multicolumn{2}{|l|}{ Gender } \\
\hline Male & $308(80.2)$ \\
\hline Female & 76 (19.8) \\
\hline \multicolumn{2}{|l|}{ Marital status } \\
\hline Currently married & $263(68.5)$ \\
\hline Currently not married & $121(31.5)$ \\
\hline \multicolumn{2}{|l|}{ Place of residence } \\
\hline Urban & $200(52.2)$ \\
\hline Rural & $184(47.8)$ \\
\hline \multicolumn{2}{|l|}{ Level of education } \\
\hline$\leq 10$ years of education & $96(25.0)$ \\
\hline $11-12$ years of education & $145(37.8)$ \\
\hline $13-14$ years of education & $96(25.0)$ \\
\hline $15-16$ years of education & $28(7.3)$ \\
\hline$\geq 17$ years of education & $19(4.9)$ \\
\hline \multicolumn{2}{|c|}{ Family monthly income (in Pakistani rupees*) } \\
\hline$<25,000$ & $104(27.1)$ \\
\hline $25,000-50,000$ & $126(32.9)$ \\
\hline $50,001-75,000$ & $112(29.1)$ \\
\hline $75,001-100,000$ & $34(8.9)$ \\
\hline$>100,000$ & $8(2.0)$ \\
\hline
\end{tabular}




\section{Ethical considerations}

The study protocols were reviewed and approved by the Institutional Review Board, University of the Punjab. The investigation's objectives were clearly explained to participants before the questionnaires were administered, and written informed consent was obtained. Respondents were informed about the ethics and their right of voluntary participation. The respondents were guaranteed confidentiality and anonymity of their responses in the publication.

\section{Results}

\section{Sociodemographic characteristics}

The majority of participants were middle-aged. About $80.2 \%$ of respondents were male and $68.5 \%$ were married. A majority, $62.8 \%$, of the participants did not have a university degree and $60.0 \%$ were earning less than 50,000 rupees per month. Almost equal proportions were from rural and urban areas (Table 1).

\section{Use of various media channels}

The research investigation involves filling out questionnaires, both before $\left(t_{1}\right)$ and after $\left(t_{2}\right)$ the first reported case of COVID-19 in Pakistan. The media was considered to be an information provider and awareness creator. People use different types of media - either exclusively or in combination - to acquire information. Different types of media correlated at a low or moderate level for each instance of data collection. However, there was a very high correlation for each type of media when comparing $t_{1}$ and $t_{2}$. The daily users of social media increased from $46.1-54.7 \%$ from $t_{1}$ to $t_{2}$. The proportion of weekly users of social media stayed almost the same. Electronic media were the most widely used among participants $\left(62.5 \%\right.$ at $t_{1}$ and $71.7 \%$ at $\left.t_{2}\right)$. The use of newspapers and magazines decreased significantly, as $64.3 \%$ of respondents were not using them in March compared to $45.1 \%$ in February (Table 2). 
Table 2

Frequency of media use before $\left(t_{1}\right)$ and after $\left(t_{2}\right)$ the first reported case of COVID-19 $(n=384)$

\begin{tabular}{|c|c|c|c|c|c|c|}
\hline \multirow[t]{2}{*}{ Type of media } & \multicolumn{3}{|c|}{$\begin{array}{l}\text { Media use at } t_{1} \\
n(\%)\end{array}$} & \multicolumn{3}{|c|}{$\begin{array}{l}\text { Media use at } t_{2} \\
n(\%)\end{array}$} \\
\hline & Daily & Weekly & $\begin{array}{l}\text { Not } \\
\text { follow }\end{array}$ & Daily & Weekly & $\begin{array}{l}\text { Not } \\
\text { follow }\end{array}$ \\
\hline $\begin{array}{l}\text { Social media } \\
\text { (e.g. Facebook, } \\
\text { WhatsApp) }\end{array}$ & $\begin{array}{l}177 \\
(46.1)\end{array}$ & $\begin{array}{l}99 \\
(25.8)\end{array}$ & $\begin{array}{l}108 \\
(28.1)\end{array}$ & $\begin{array}{l}210 \\
(54.7)\end{array}$ & $\begin{array}{l}95 \\
(24.7)\end{array}$ & 79 (20.6) \\
\hline $\begin{array}{l}\text { Electronic media } \\
\text { (e.g. television) }\end{array}$ & $\begin{array}{l}240 \\
(62.5)\end{array}$ & $\begin{array}{l}72 \\
(18.8)\end{array}$ & $72(18.8)$ & $\begin{array}{l}273 \\
(71.7)\end{array}$ & $\begin{array}{l}59 \\
(15.4)\end{array}$ & $52(13.5)$ \\
\hline $\begin{array}{l}\text { Print media } \\
\text { (e.g. newspaper, } \\
\text { magazine) }\end{array}$ & $\begin{array}{l}150 \\
(39.1)\end{array}$ & $\begin{array}{l}61 \\
(15.9)\end{array}$ & $\begin{array}{l}173 \\
(45.1)\end{array}$ & 97 (25.3) & $\begin{array}{l}40 \\
(10.4)\end{array}$ & $\begin{array}{l}247 \\
(64.3)\end{array}$ \\
\hline
\end{tabular}

\section{Awareness and knowledge related to COVID-19}

The first response in February depicts an overall low level of knowledge regarding COVID-19 among participants. At $t_{1}, 37.5 \%$ of respondents knew that the coronavirus is a contagious viral disease, whereas $51.8 \%$ were aware of the transmittable nature of coronavirus at $t_{2}$. The droplet route of coronavirus transmission was known to $29.2 \%\left(t_{1}\right)$ and $42.4 \%\left(t_{2}\right)$ of the sampled population. That coughing and sneezing of viral material spreads the infection to healthy people was correctly identified by $36.7 \%$ of the respondents initially and that knowledge level had increased to $63.3 \%$ in the second response. At $t_{1}$, $22.7 \%$ of participants knew that coronavirus treatment is only supportive, while $51.6 \%$ confirmed this statement at $t_{2}$. In February, $15.4 \%$ erroneously judged the statement that a vaccine is available to be correct, whereas only $0.5 \%$ did so in March (Table 3 ). 
Table 3

Correct knowledge related to COVID-19 in February $\left(t_{1}\right)$ and March $\left(t_{2}\right) 2020(n=384)$

\begin{tabular}{|c|c|c|}
\hline Variables & $\begin{array}{l}t_{1} \\
n(\%)\end{array}$ & $\begin{array}{l}t_{2} \\
n(\%)\end{array}$ \\
\hline \multicolumn{3}{|l|}{ Coronavirus general awareness } \\
\hline Coronavirus is a contagious viral disease & $\begin{array}{l}144 \\
(37.5)\end{array}$ & $\begin{array}{l}199 \\
(51.8)\end{array}$ \\
\hline Coronavirus spreads via droplet infection & $\begin{array}{l}112 \\
(29.2)\end{array}$ & $\begin{array}{l}163 \\
(42.4)\end{array}$ \\
\hline $\begin{array}{l}\text { Coronavirus spreads through coughing and sneezing of the infected } \\
\text { person }\end{array}$ & $\begin{array}{l}141 \\
(36.7)\end{array}$ & $\begin{array}{l}243 \\
(63.3)\end{array}$ \\
\hline Coronavirus treatment is only supportive & $87(22.7)$ & $\begin{array}{l}198 \\
(51.6)\end{array}$ \\
\hline Coronavirus vaccine is available (wrong statement) & $\begin{array}{l}325 \\
(84.6)\end{array}$ & $\begin{array}{l}382 \\
(99.5)\end{array}$ \\
\hline \multicolumn{3}{|l|}{ Knowledge regarding symptoms of COVID-19 } \\
\hline Fever & $\begin{array}{l}105 \\
(27.3)\end{array}$ & $\begin{array}{l}263 \\
(68.5)\end{array}$ \\
\hline Cough & $81(21.2)$ & $\begin{array}{l}249 \\
(64.8)\end{array}$ \\
\hline Body aches & $\begin{array}{l}133 \\
(34.6)\end{array}$ & $\begin{array}{l}262 \\
(68.2)\end{array}$ \\
\hline Shortness of breath & $\begin{array}{l}105 \\
(27.3)\end{array}$ & $\begin{array}{l}259 \\
(67.4)\end{array}$ \\
\hline \multicolumn{3}{|l|}{ Complications of COVID-19 } \\
\hline Pneumonia & $76(19.8)$ & $94(24.5)$ \\
\hline Organ failure & $85(22.1)$ & $\begin{array}{l}126 \\
(32.8)\end{array}$ \\
\hline \multicolumn{3}{|l|}{ Preventive measures to be adopted for COVID-19 } \\
\hline Frequent hand washing with soap for 20 seconds & $\begin{array}{l}123 \\
(32.0)\end{array}$ & $\begin{array}{l}328 \\
(85.4)\end{array}$ \\
\hline Following cough and sneeze etiquette & $\begin{array}{l}158 \\
(41.4)\end{array}$ & $\begin{array}{l}216 \\
(56.3)\end{array}$ \\
\hline Avoid social contact with sick people & $\begin{array}{l}109 \\
(28.4)\end{array}$ & $\begin{array}{l}213 \\
(55.5)\end{array}$ \\
\hline Use of face mask & $\begin{array}{l}130 \\
(33.9)\end{array}$ & $\begin{array}{l}203 \\
(52.9)\end{array}$ \\
\hline
\end{tabular}




\begin{tabular}{|lll|}
\hline Variables & $t_{1}$ & $\boldsymbol{t}_{\mathbf{2}}$ \\
\hline Use of sanitizer & $n(\%)$ & $\boldsymbol{n}(\%)$ \\
\hline Isolation of suspected cases & 139 & 253 \\
& $(36.2)$ & $(65.9)$ \\
\hline Lockdown effect in countries during COVID-19 & 109 & 205 \\
\hline Helps to follow social distancing & $(28.4)$ & $(53.4)$ \\
\hline Results in more self-protection & & \\
\hline
\end{tabular}

Awareness regarding the symptoms of COVID-19 indicated a noteworthy increase in knowledge among participants. At $t_{1}$, about one third provided correct responses to all the different kinds of symptoms, whereas this was about two thirds at $t_{2}$. The general public's correct response rate related to complications of COVID-19 was much lower. Fewer than 23\% in February and fewer than $33 \%$ in March identified pneumonia and organ failure as complications of COVID-19 (Table 3).

The results of the questions about preventive measures to be adopted indicated that $32 \%$ of respondents were conscious of frequent handwashing in February. This response had increased significantly to $85.4 \%$ in March. For all other preventive measures, the correct responses increased as well, but at a lower level, from about one third correct answers to slightly more than half. Whereas only a quarter of respondents judged the isolation of suspected cases in quarantine to be important for preventing the spread of infection in society at $t_{1}$, more than half did so at $t_{2}$. The same increase was visible in relation to the statement that a lockdown helps to follow social distancing (Table 3).

\section{Knowledge gains over time and associated factors}

The changes within three subscales related to COVID-19 awareness (general, symptoms, and preventive measures), as well as total awareness as the combination of all three subscales, are presented in terms of mean differences in Table 4. For all scales, knowledge increased significantly over time. 
Table 4

Knowledge related to COVID-19 in February $\left(t_{1}\right)$ compared to March $\left(t_{2}\right) 2020(n=384)$

\begin{tabular}{|c|c|c|c|c|c|}
\hline Variables & Time & Mean & $S D$ & Mean difference & $p$-value \\
\hline \multirow{2}{*}{$\begin{array}{l}\text { Coronavirus general awareness } \\
\text { ( } 5 \text { items) }\end{array}$} & $t_{1}$ & 2.11 & 1.43 & \multirow[t]{2}{*}{0.97} & \multirow[t]{2}{*}{$<0.001$} \\
\hline & $t_{2}$ & 3.08 & 1.49 & & \\
\hline \multirow{2}{*}{$\begin{array}{l}\text { Symptoms of COVID-19 } \\
\text { (6 items) }\end{array}$} & $t_{1}$ & 1.52 & 2.20 & \multirow[t]{2}{*}{1.74} & \multirow[t]{2}{*}{$<0.001$} \\
\hline & $t_{2}$ & 3.26 & 1.49 & & \\
\hline \multirow{2}{*}{$\begin{array}{l}\text { Preventive measures to be adopted } \\
\text { (8 items) }\end{array}$} & $t_{1}$ & 2.53 & 2.69 & \multirow[t]{2}{*}{2.30} & \multirow[t]{2}{*}{$<0.001$} \\
\hline & $t_{2}$ & 4.83 & 1.71 & & \\
\hline \multirow{2}{*}{$\begin{array}{l}\text { Total } \\
\text { (19 items) }\end{array}$} & $t_{1}$ & 6.16 & 5.80 & \multirow[t]{2}{*}{5.02} & \multirow[t]{2}{*}{$<0.001$} \\
\hline & $t_{2}$ & 11.18 & 3.71 & & \\
\hline
\end{tabular}

Using three linear regression models, we analysed the factors associated with knowledge (all knowledge items combined in one score) related to COVID-19 at $t_{1}$, at $t_{2}$, and those factors associated with knowledge gains over time (between $\mathrm{t}_{1}$ and $\mathrm{t}_{2}$ ). Socio-demographic characteristics are not significantly associated with knowledge, except for an inverse relationship with income at $t_{2}$. Although not significant, people of younger age, female, and living in urban areas had a greater likelihood of better knowledge related to COVID-19 at both $t_{1}$ and $t_{2}$. Nevertheless, knowledge gains were higher within those groups with lower knowledge levels at $t_{1}$. Respondents with a higher educational level had greater knowledge at $t_{1}$ and $t_{2}$, and also demonstrated greater knowledge gains.

More frequent use of social media and electronic media is associated with lower levels of knowledge in both surveys. Although the use of electronic media is significantly inversely related to knowledge at both $t_{1}$ and $t_{2}$, this does not hold for the changes in knowledge over time: more frequent use of electronic media is associated with higher knowledge gains from $t_{1}$ to $t_{2}(B=0.522, p=0.018)$. The variance explained by the variables included in the models is less than $5 \%$ for all three models (Table 5 ). 
Table 5

Factors associated with knowledge (gains) related to COVID-19 $(n=384)$

\begin{tabular}{|c|c|c|c|c|c|c|c|c|c|}
\hline & \multicolumn{3}{|l|}{$t_{1}$} & \multicolumn{3}{|l|}{$t_{2}$} & \multicolumn{3}{|c|}{ Knowledge gain ( $t_{1}$ to $\left.t_{2}\right)$} \\
\hline & B & $\mathrm{T}$ & $\begin{array}{l}\mathrm{p}- \\
\text { value }\end{array}$ & B & $\mathrm{T}$ & $\begin{array}{l}p- \\
\text { value }\end{array}$ & B & $\mathrm{T}$ & $\begin{array}{l}\mathrm{p}- \\
\text { value }\end{array}$ \\
\hline Age & -0.327 & -1.056 & 0.292 & -0.108 & -0.553 & 0.581 & 0.164 & 1.016 & 0.310 \\
\hline Gender & 1.021 & 1.365 & 0.173 & 0.639 & 1.351 & 0.178 & -0.482 & -1.234 & 0.218 \\
\hline Residence & -0.842 & -1.413 & 0.158 & -0.722 & -1.905 & 0.058 & 0.067 & 0.214 & 0.830 \\
\hline Education & 0.263 & 0.375 & 0.708 & 0.335 & 0.756 & 0.450 & 0.032 & 0.088 & 0.930 \\
\hline Income & -0.186 & -0.570 & 0.569 & -0.465 & -2.210 & 0.028 & -0.293 & -1.687 & 0.093 \\
\hline Social media & -0.305 & -0.869 & 0.385 & -0.037 & -0.158 & 0.875 & 0.042 & 0.214 & 0.831 \\
\hline $\begin{array}{l}\text { Electronic } \\
\text { media }\end{array}$ & -0.961 & -2.462 & 0.014 & -0.575 & -2.156 & 0.032 & 0.522 & 2.373 & 0.018 \\
\hline Print media & 0.340 & 1.025 & 0.306 & 0.013 & 0.058 & 0.954 & -0.156 & -0.861 & 0.390 \\
\hline Constant & 9.486 & 4.122 & $<.001$ & 13.915 & 9.184 & $<.001$ & 4.474 & 3.577 & $\begin{array}{l}< \\
0.001\end{array}$ \\
\hline $\mathrm{R}^{2}$ & 0.036 & & & 0.045 & & & 0.035 & & \\
\hline
\end{tabular}

\section{Relationship between gender, residence, and information related to COVID-19}

Answers relating to preventive measures to be adopted at $t_{1}$ are significantly associated with gender and residence (Table 6). 
Table 6

Relationship between gender, residence and information related to COVID-19 ( $n=384)$

$\begin{array}{lllll}\text { Variables Response } & \text { Percentages } & \begin{array}{l}\text { p- } \\ \text { value }\end{array} & \text { Percentages } & \text { p-value }\end{array}$

\section{Gender}

Coronavirus general awareness at $\mathrm{t}_{1}$

Coronavirus general awareness at $\mathrm{t}_{2}$

Male

Having knowledge $\quad 34.4 \%$

0.00

0.97

$43.5 \%$

0.00

0.98

Not having

$65.6 \%$

$56.5 \%$

knowledge

Female

Having knowledge $\quad 34.2 \%$

$65.8 \%$

Not having

knowledge

Symptoms of COVID-19 at $t_{1}$

Symptoms of COVID-19 at $t_{2}$

\begin{tabular}{llllllll} 
Male & Having knowledge & $34.4 \%$ & 0.00 & 0.97 & $43.5 \%$ & 3.47 & 0.06 \\
\cline { 1 - 2 } $\begin{array}{l}\text { Not having } \\
\text { knowledge }\end{array}$ & $65.6 \%$ & & & $56.5 \%$ & &
\end{tabular}

Female Having knowledge $\quad 34.2 \%$

$43.4 \%$

Not having

$65.8 \%$

$56.6 \%$

knowledge

Preventive measures to be adopted at $t_{1}$

Preventive measures to be adopted at $\mathrm{t}_{2}$

Male

Having knowledge $\quad 27.6 \%$

$4.900 .04^{\star}$

$53.2 \%$

0.25

0.61

Not having

$72.4 \%$

knowledge

Female Having knowledge $\quad 39.5 \%$

Not having

knowledge

$60.5 \%$

$46.8 \%$

$50.0 \%$

$50.0 \%$

\section{Residence}

Coronavirus general awareness at $t_{1}$

Coronavirus general awareness at $\mathrm{t}_{2}$

Urban

\begin{tabular}{ll} 
Having knowledge & $37.0 \%$ \\
\hline $\begin{array}{l}\text { Not having } \\
\text { knowledge }\end{array}$ & $63.0 \%$ \\
\hline
\end{tabular}

1.27

0.25

$46.0 \%$

1.07

0.30

knowledge

* indicates level of significance at 0.05 


\begin{tabular}{|c|c|c|c|c|c|c|c|}
\hline Variables & Response & Percentages & & $\begin{array}{l}\mathrm{p}- \\
\text { value }\end{array}$ & Percentages & & p-value \\
\hline \multirow[t]{2}{*}{ Rural } & Having knowledge & $31.5 \%$ & & & $40.8 \%$ & & \\
\hline & $\begin{array}{l}\text { Not having } \\
\text { knowledge }\end{array}$ & $68.5 \%$ & & & $59.2 \%$ & & \\
\hline \multicolumn{5}{|c|}{ Symptoms of COVID-19 at $t_{1}$} & \multicolumn{3}{|c|}{ Symptoms of COVID-19 at $t_{2}$} \\
\hline \multirow[t]{2}{*}{ Urban } & Having knowledge & $32.0 \%$ & \multirow[t]{4}{*}{1.33} & \multirow[t]{4}{*}{0.24} & $63.0 \%$ & 3.34 & 0.06 \\
\hline & $\begin{array}{l}\text { Not having } \\
\text { knowledge }\end{array}$ & $68.0 \%$ & & & $37.0 \%$ & & \\
\hline \multirow[t]{2}{*}{ Rural } & Having knowledge & $26.6 \%$ & & & $53.8 \%$ & & \\
\hline & $\begin{array}{l}\text { Not having } \\
\text { knowledge }\end{array}$ & $73.4 \%$ & & & $46.2 \%$ & & \\
\hline \multicolumn{5}{|c|}{ Preventive measures to be adopted at $t_{1}$} & \multicolumn{3}{|c|}{$\begin{array}{l}\text { Preventive measures to be } \\
\text { adopted at } t_{2}\end{array}$} \\
\hline \multirow[t]{2}{*}{ Urban } & Having knowledge & $35.0 \%$ & \multirow[t]{4}{*}{5.07} & \multirow[t]{4}{*}{$0.02^{\star}$} & $54.5 \%$ & 0.60 & 0.43 \\
\hline & $\begin{array}{l}\text { Not having } \\
\text { knowledge }\end{array}$ & $65.0 \%$ & & & $45.5 \%$ & & \\
\hline \multirow[t]{2}{*}{ Rural } & Having knowledge & $24.5 \%$ & & & $50.5 \%$ & & \\
\hline & $\begin{array}{l}\text { Not having } \\
\text { knowledge }\end{array}$ & $75.5 \%$ & & & $49.5 \%$ & & \\
\hline
\end{tabular}

\section{Discussion}

The COVID-19 pandemic is one of the most challenging threats to society and public health since World War II, due to its global spread and its effects on almost every aspect of life. The media as a social organization may play a vital role because it endorses adaptive measures to promote awareness and knowledge about health-related issues and encourages compliance with precautionary actions. The media enjoys widespread rapid access, and, therefore, serves as the major source of information for the general public during the infodemic of COVID-19. An infodemic, as defined by the WHO, requires a decrease in the transmission of false information to the general public (25). Defective and fabricated information will create panic among the masses and affect the psychological well-being of society (26).

The COVID-19 epidemic in Wuhan, China, was reported worldwide, including in Pakistan (27). More focused reporting was observed in the media after its global spread, as emphasized by social responsibility theory. The theory of social responsibility states that it is the professional obligation of the media to recognize the needs of the community (28). Pakistani print, electronic, and social media placed 
more emphasis on the adoption of preventive measures after the first case was reported in Karachi, Sindh, on 26 February 2020. The use of mass media during the initial phases of the event as a quick, effective, and evident mediator was also suggested by Rogers (29). Media outlets in Pakistan are covering the daily COVID-19 statistics. Lockdown in Pakistan led the general public to be concerned about the 2019 Novel Coronavirus (21-23). The present research investigation evaluated the role of media awareness campaigns in shaping the perceptions of the general population towards COVID-19 in Rawalpindi. The general population utilized different types of media during the COVID-19 pandemic to access information (30). Our investigation shows that the number of users of social and electronic media increased during the coronavirus pandemic, a finding that is reinforced by further international surveys $(31,32)$. The number of users of print media decreased in the present study between $t_{1}$ and $t_{2}$ due to fears that coronavirus may be transmitted through the newspaper or by the vendor (33). Similar results were reported in India (34).

Pakistan is a male-dominated society; therefore, the majority of participants visiting the research investigation site were male (35) because tasks outside the home are considered to be the responsibility of males. Although gender inequalities have been reported in the education system in Pakistan (36), no significant differences in gender responses were observed in relation to general awareness or knowledge of the symptoms of COVID-19 in either the pre- or the post-response. Education plays an important role in understanding the medical awareness (37). Overall low levels of health literacy in any section of the final response may be correlated with the low proportion of postgraduate respondents, as well as the large number of respondents from rural areas (18). Information inequalities may be linked with socioeconomic disparities because almost $90 \%$ of the respondents' families were earning less than 75,000 Pakistani rupees, which is an aspect closely linked with low health literacy levels $(37,38)$.

In Pakistan, many people, especially from rural areas, have the belief that there is no coronavirus and the news items related to COVID-19 are just exaggerations by the media. Nearly half of the sampled population in this investigation was from a rural background. The knowledge level was lower in the rural sample than in the urban sample. Although there was an increase in COVID-related knowledge among the rural population after the media awareness campaign in the country, still half of the rural group was ignorant of important aspects. The lack of awareness and misconceptions associated with COVID-19 in the rural populace may be interconnected with low literacy and the prevalence of conspiracy theories (39). Less educated individuals are more likely to believe in false myths. The infodemic believers need immediate behavioural modification through the involvement of social workers to minimize the spread of incorrect information. However, the conspiracy theories against COVID-19 are prevalent not only in Pakistan but also in other countries at a global level due to the novelty of the virus (40).

Overall, the respondents' knowledge related to the coronavirus increased. However, one needs to critically judge whether the anticipated outcomes were achieved solely through effective communication strategies based on the theory of planned behaviour (41). Moderate COVID-19 awareness among the general population has been reported in India (42). The level of awareness has been assessed as high among residents of China (43). Our study provides some hints that electronic media in particular may 
lead to knowledge gains. However, the ubiquitous presence of COVID-19 in the media makes comparisons between low and high levels of exposure to media campaigns quite challenging. Furthermore, the diffusion of innovation theory also proposes that acceptance takes time and that individuals pass through various phases in the adoption procedure and may acclimatize to the concept during the later phases. Therefore, future investigations may discover improved health awareness among participants related to further items, whereas only limited progress was seen in our study, such as that related to the complications of COVID-19 (28).

The media as a modification agent can affect the behaviour of individuals to enable improved well-being by acclimatizing them to the precautionary measures that halt the spread of the virus. Prevention is the essence of public health (44). China successfully controlled the epidemic in Wuhan by applying the preventive approach (45). It is the responsibility of the media to provide timely and correct information for health education and the promotion of prevention strategies. The government, in collaboration with the media, has to address the challenge of information inequalities. Rich clients of the media in Pakistan have access to high-quality and timely information. But information regarding COVID-19 is also the right of people living in rural areas (18) and of vulnerable populations, such as refugees. There is a need for guidance to recognize the importance of the media for disseminating information related to the coronavirus. Health journalism requires sound knowledge related to infectious diseases. Lack of knowledge makes it challenging for journalists to describe this public health pandemic.

\section{Limitations}

Our study sheds some light on the importance of the media in these times of the coronavirus pandemic. The results are valuable due to the large sample size. The response rate of $100 \%$ - without any missing items - indicates that the public is highly aware of the topic. However, the results need to be interpreted with caution because this research does not allow for a classical randomized or experimental study design. We were only able to distinguish between the frequency of use of various media channels. Because of the almost ubiquitous prevalence of information related to COVID-19, one might expect that even a relatively low frequency of media exposure provides information to the public. Furthermore, the results of the linear regression models indicate that there are more variables that were not included (known unknowns such as health status or interest in health-related issues, but also further unknown unknowns), which may further impact upon awareness and knowledge related to COVID-19.

\section{Conclusions}

The results of this study show an overall positive effect in knowledge gains related to COVID-19, which are at least partially attributable to health-related media campaigns. These campaigns can encourage healthy behaviours and avoid undesirable deviations in behaviour among targeted populations. The investigation also highlighted the choice of media used by the participants. The numbers of social and electronic media users increased significantly during the coronavirus pandemic. It is important to communicate preventive information via the most frequently searched media to enable rapid circulation. 
Low preventive health awareness was associated with socioeconomically deprived groups. There is a need to develop user-friendly and indigenous communication strategies to improve the health literacy of the masses. Active collaboration between the government and media stakeholders is vital to safeguard the population during the COVID-19 pandemic.

The survey suggested a need for pilot studies utilizing the media during pandemics and epidemics by healthcare stakeholders for the development of rapid and timely information communication strategies. Infodemics related to infectious diseases should be addressed through effective policymaking and implementation. There is a need for training in infectious disease reporting for journalists on rational health communication so that infodemics can be avoided in future outbreaks. Governments should address challenges to overcome health communication barriers among different social classes.

\section{Abbreviations}

\begin{tabular}{ll} 
COVID-19: & Novel Coronavirus Disease 2019 \\
\hline MERS: & Middle East Respiratory Syndrome \\
\hline SARS: & Severe Acute Respiratory Syndrome \\
\hline SPSS: & Statistical Package for the Social Sciences \\
\hline WHO: & World Health Organization
\end{tabular}

\section{Declarations}

\section{Ethical Approval and Consent to Participate}

The study protocol was reviewed and approved by the Institutional Review Board, University of the Punjab. Respondents were informed about the ethics and right of voluntary participation. Before the questionnaires were administered written informed consent was obtained.

\section{Consent for Publication}

Not applicable.

\section{Availability of Data and Materials}

Data is available from corresponding author upon reasonable request.

\section{Competing Interest}


The authors declare that no competing interest exist. FF serves on the Editorial Board of BMC Public Health as Associate Editor.

\section{Funding}

This research received no supporting funds from any funding agency in the public, commercial, or not-forprofit sector.

\section{Authors Contributions}

AR and RZ conceptualized the study. AR and UH contributed to data collection. RZ, MZZ, and FF supervised the work and supported in data analysis. AR, RZ and UH drafted the draft. All authors contributed to revising the manuscript and approved the final manuscript.

\section{Acknowledgements}

We acknowledge support from the German Research Foundation (DFG) and the Open Access Publication Fund of Charité - Universitätsmedizin Berlin.

\section{References}

1. Sohrabi C, Alsafi Z, O'Neill N, Khan M, Kerwan A, Al-Jabir A et al. World Health Organization declares global emergency: A review of the 2019 novel coronavirus (COVID-19). Int J Surg. 2020;76:71-6.

2. Kawana A. SARS, MERS and coronavirus infections. Nihon Rinsho. 2016;74(12):1967-72.

3. Desforges M, Le Coupanec A, Dubeau P, Bourgouin A, Lajoie L, Dubé M et al. Human Coronaviruses and Other Respiratory Viruses: Underestimated Opportunistic Pathogens of the Central Nervous System? Viruses. 2020;12(1):14.

4. Jiang S, Du L, Shi Z. An emerging coronavirus causing pneumonia outbreak in Wuhan, China: calling for developing therapeutic and prophylactic strategies. Emerg Microbes Infect. 2020;9(1):275-7.

5. Badshah SL, Ullah A, Badshah SH, Ahmad I. Spread of Novel Coronavirus by Returning Pilgrims from Iran to Pakistan. Journal of Travel Medicine. 2020;27(3):taaa044.

6. Covid-19 Dashboard. Ministry of National Health Services Regulations \& Coordination, 2020. Available online: http://covid.gov.pk/stats/pakistan (accessed September 9, 2020).

7. Khan Y, O'Sullivan T, Brown A, Tracey S, Gibson J, Genereux M et al. Public health emergency preparedness: a framework to promote resilience. BMC Public Health. 2018;18(1):1344.

8. Torani S, Majd PM, Maroufi SS, Dowlati M, Sheikhi RA. The importance of education on disasters and emergencies: A review article. J Educ Health Promot. 2019;8:85. 
9. Wakefield MA, Loken B, Hornik RC. Use of mass media campaigns to change health behaviour. Lancet. 2010;376(9748):1261-71.

10. Suresh K. Evidence based communication for health promotion: Indian lessons of last decade. Indian Journal of Public Health. 2011;55(4):276.

11. Dali AS. Health Interventions to Promote the Polio Vaccine within the Global Polio Eradication Initiative: A Systematic Review From 2000-2014. Atlanta: Georgia State University; 2017.

12. Sharma SK, Gupta YK. Mass Media for Health Education (A Study in the State of Rajasthan). Multidisciplinary International Journal. 2017;1(1):26-39.

13. WHO. WHO supports Government of Pakistan in strengthening novel coronavirus preparedness and response. 2020. Available online: http://www.emro.who.int/pak/pakistan-news/who-supportsgovernment-of-pakistan-in-strengthening-novel-coronavirus-preparedness-response.html (accessed April 10, 2020).

14. Dong M, Zheng J. Letter to the editor: Headline stress disorder caused by Netnews during the outbreak of COVID-19. Health Expect. 2020;23(2):259-60.

15. Jin $Y-H$, Cai L, Cheng Z-S, Cheng H, Deng T, Fan Y-P et al. A rapid advice guideline for the diagnosis and treatment of 2019 novel coronavirus (2019-nCoV) infected pneumonia (standard version). Military Medical Research. 2020;7(1):4.

16. Pang J, Wang MX, Ang IYH, Tan SHX, Lewis RF, Chen Jl et al. Potential Rapid Diagnostics, Vaccine and Therapeutics for 2019 Novel Coronavirus (2019-nCoV): A Systematic Review. J Clin Med. 2020;9(3):623.

17. Adhikari SP, Meng S, Wu Y-J, Mao Y-P, Ye R-X, Wang Q-Z et al. Epidemiology, causes, clinical manifestation and diagnosis, prevention and control of coronavirus disease (COVID-19) during the early outbreak period: a scoping review. Infectious Diseases of Poverty. 2020;9(1):29.

18. Blum AJ, Majid MF, Hotez PJ. Pakistan: A nation held back by NTDs. PLoS Negl Trop Dis. 2018;12(10):e0006751.

19. Reporter TNsS. Sudden surge in Punjab coronavirus cases after Eid. Dawn. August 7, 2020.

20. Arya R, Antonisamy B, Garg SK. Sample Size Estimation in Prevalence Studies. Indian Journal of Pediatrics. 2012;79(11):1482-8.

21. Younus U. Coronavirus hits Pakistan's already-strained economy, and its most vulnerable. Atlantic council. March 30, 2020.

22. Murtaza H. Role of information technology and social media in deadly COVID-19 crisis. Daily times. April 6, 2020.

23. Corona Virus Public Awareness Campaign. 2020. Available online: https://reliefweb.int/report/pakistan/corona-virus-public-awareness-campaign (accessed April 10, 2020).

24. Dembe AE, Partridge JS, Geist LC. Statistical software applications used in health services research: analysis of published studies in the U.S. BMC Health Serv Res. 2011;11:252. 
25. Zarocostas J. How to fight an infodemic. Lancet. 2020;395(10225):676.

26. Hugman B. The Erice declaration: The critical role of communication in drug safety. Drug Safety. 2006;29:91-3.

27. A6rshad Ali S, Baloch M, Ahmed N, Arshad Ali A, lqbal A. The outbreak of Coronavirus Disease 2019 (COVID-19): An emerging global health threat. J Infect Public Health. 2020;13(4):644-46.

28. Institute of Medicine (US) Committee on Assuring the Health of the Public in the 21st Century. The future of the public health in the 21 st century. Washington, D.C.: National Academies Press; 2003.

29. Rogers EM. Diffusion of innovations. New York: Simon and Schuster; 2010.

30. Aslani P. What are our health expectations in a pandemic? Health Expect. 2020;23(2):257-8.

31. Social Media Today. People Are Spending 20\% More Time in Apps During the COVID-19 Lockdowns. 2020. Available online: https://www.socialmediatoday.com/news/people-are-spending-20-more-timein-apps-during-the-covid-19-lockdowns-re/575403/ (accessed April 15, 2020).

32. WARC. India's TV and mobile consumption spikes as COVID-19 lockdown progresses. 2020. Available online: https://www.warc.com/newsandopinion/news/indias-tv-and-mobile-consumptionspikes-as-covid-19-lockdown-progresses/43427 (accessed April 15, 2020).

33. Kampf G, Todt D, Pfaender S, Steinmann E. Persistence of coronaviruses on inanimate surfaces and its inactivation with biocidal agents. J Hosp Infect. 2020;104(3):246-51.

34. Covid-19 hits print media hard - ads and circulation dip, editions see major digital push. 2020. Available online: https://theprint.in/india/covid-19-hits-print-media-hard-ads-and-circulation-dipeditions-see-major-digital-push/388514/ (accessed April 15, 2020).

35. Ali TS, Krantz G, Gul R, Asad N, Johansson E, Mogren I. Gender roles and their influence on life prospects for women in urban Karachi, Pakistan: a qualitative study. Glob Health Action. 2011;4:7448.

36. Hahn RA, Truman BI. Education Improves Public Health and Promotes Health Equity. Int J Health Serv. 2015;45(4):657-78.

37. Bailey A, Porter K, Hill JL, Chen Y, Estabrooks PA, Zoellner J. The impact of health literacy on rural adults' satisfaction with a multi-component intervention to reduce sugar-sweetened beverage intake. Health Educ Res. 2016;31(4):492-508.

38. Golboni F, Nadrian H, Najafi S, Shirzadi S, Mahmoodi H. Urban-rural differences in health literacy and its determinants in Iran: A community-based study. Aust J Rural Health. 2018;26(2):98-105.

39. Frieden J. Lack of Health Literacy a Barrier to Grasping COVID-19. MEDPAGE TODAY. June 10, 2020.

40. Georgiou N, Delfabbro P, Balzan R. COVID-19-related conspiracy beliefs and their relationship with perceived stress and pre-existing conspiracy beliefs. Pers Individ Dif. 2020;166:110201.

41. Stead M, Tagg S, MacKintosh AM, Eadie D. Development and evaluation of a mass media Theory of Planned Behaviour intervention to reduce speeding. Health Educ Res. 2005;20(1):36-50.

42. Roy D, Tripathy S, Kar SK, Sharma N, Verma SK, Kaushal V. Study of knowledge, attitude, anxiety \& perceived mental healthcare need in Indian population during COVID-19 pandemic. Asian J Psychiatr. 
2020;51:102083.

43. Zhong BL, Luo W, Li HM, Zhang QQ, Liu XG, Li WT et al. Knowledge, attitudes, and practices towards COVID-19 among Chinese residents during the rapid rise period of the COVID-19 outbreak: a quick online cross-sectional survey. Int J Biol Sci. 2020;16(10):1745-52.

44. Ali A, Katz DL. Disease prevention and health promotion: how integrative medicine fits. Am J Prev Med. 2015;49(5):S230-40.

45. Tian H, Liu Y, Li Y, Wu C-H, Chen B, Kraemer MU et al. An investigation of transmission control measures during the first 50 days of the COVID-19 epidemic in China. Science. 2020; 368(6491):638-42.

\section{Supplementary Files}

This is a list of supplementary files associated with this preprint. Click to download.

- Supplementaryappendix1Questionnaire.pdf 